\title{
Działalność Instytutu Nauk Biblijnych KUL w roku akademickim 2018/2019
}

Academic Activity of the Institute of Biblical Studies CUL in the Year 2018/2019

\author{
TOMASZ BARTŁOMIEJ BĄK \\ Sekcja Nauk Biblijnych, Katolicki Uniwersytet Lubelski Jana Pawła II \\ e-mail: tomciobak@gmail.com \\ ORCID: 0000-0003-0328-0282
}

\section{Sprawy personalne}

W roku akademickim 2018/2019 Instytut Nauk Biblijnych działał w ramach czterech katedr:

\section{Katedra Egzegezy Ksiąg Historycznych, Prorockich i Sapiencjalnych}

Kierownik - ks. dr hab. Dariusz Dziadosz

Pracownicy:

- ks. dr hab. Andrzej Piwowar

- ks. dr Krzysztof Napora SCJ

- ks. dr Arnold Zawadzki

\section{Katedra Egzegezy Ewangelii i Pism Apostolskich}

Kierownik - dr hab. Krzysztof Mielcarek, prof. KUL

Pracownicy:

- ks. prof. dr hab. Stefan Szymik

- ks. dr hab. Adam Kubiś 


\section{Katedra Filologii Biblijnej i Literatury Międzytestamentalnej}

Kierownik - ks. prof. dr hab. Mirosław Stanisław Wróbel

Pracownicy:

- ks. dr hab. Henryk Drawnel, prof. KUL

- ks. dr Tomasz Bąk

\section{Katedra Teologii Biblijnej i Proforystyki}

Kierownik - ks. prof. dr hab. Henryk Witczyk

Pracownicy:

- ks. dr hab. Marcin Kowalski

- ks. dr Marcin Zieliński

\section{Ważniejsze wydarzenia naukowe i organizacyjne}

W dniach 8-19 października 2018 r., w ramach umowy pomiędzy Katolickim Uniwersytetem Lubelskim Jana Pawła II a Papieskim Uniwersytetem Urbaniana w Rzymie, w Instytucie Nauk Biblijnych gościł ks. prof. Francesco Bianchini. Dla doktorantów INB oraz dla wszystkich zainteresowanych studentów prowadził on wykład „Egzegeza i teologia listu do Galatów” w wymiarze 30 godzin (w języku angielskim). Jego wystąpienia obejmowały historyczne, literackie i teologiczne ujęcie Listu do Galatów przy zastosowaniu metody retorycznej.

W dniach 7-20 października 2018 r. pracownik INB KUL ks. dr Marcin Zieliński gościł na Papieskim Uniwersytecie Urbaniana w Rzymie w charakterze visiting professor. Prowadził wykłady „Joy and Sorrow in the Book of Wisdom”, analizujące temat biblijnej radości i smutku w kontekście filozofii hellenistycznej. Wykłady na Uniwersytecie Urbaniana przeprowadzane są od 3 lat w ramach umowy o współpracy KUL z tą papieską uczelnią.

W dniu 27 lutego 2019 r., dzięki zaangażowaniu dyrektora Instytutu Nauk Biblijnych KUL ks. prof. dr. hab. Mirosława Wróbla, a także dwóch pracowników instytutu: ks. dr. hab. Marcina Kowalskiego oraz ks. dr. hab. Adama Kubisia, podpisano umowę o współpracy Katolickiego Uniwersytetu Lubelskiego Jana Pawła II z polonijnym Wyższym Seminarium Duchownym w Orchard Lake w USA. Reprezentantami stron byli ks. prof. dr hab. Antoni Dębiński, rektor KUL oraz ks. prałat Mirosław Król, rektor Seminarium im. Cyryla i Metodego w Orchard Lake. 
W dniu 3 kwietnia 2019 r. Instytut Nauk Biblijnych KUL gościł panią prorektor dr Osnat Argaman z Gordon Academic College of Education w Hajife w Izraelu. Obecność pani prorektor połączona była z wykładem: „,The Importance of Hebrew Language for Biblical Studies" przeprowadzonym dla studentów i pracowników naszego Instytutu.

W dniu 28 maja 2019 r. Instytut Nauk Biblijnych KUL oraz Instytut Teologii Duchowości KUL zorganizowały piąte sympozjum z cyklu Duchowość Ziemi Świętej. Tematem sympozjum była „Kobieta w Biblii oraz kulturze Bliskiego Wschodu".

Dzieło Biblijne im. św. Jana Pawła II we współpracy z Instytutem Nauk Biblijnych KUL, Wyższym Seminarium Duchownym w Paradyżu oraz moderatorami diecezjalnymi Dzieła Biblijnego zorganizowały i przeprowadziły XII Ogólnopolski Konkurs Biblijny dla Kleryków. Przedmiotem konkursu były Księga Tobiasza i Księga Judyty oraz książka: C.M. Martiniego, Spotkania z Biblia (Kraków: Wydawnictwo M 2001). Pierwszy etap konkursu odbył się 22 marca 2019 i wyłonił 53 finalistów. Etap finałowy został rozegrany w Warszawie w dniach 10-11 maja 2019 r. w ośrodku „Dobre Miejsce” i wyłonił trzech finalistów:

1. Dawid Bujas (franciszkanie konwentualni - Kraków),

2. Patryk Korcz (diecezja radomska),

3. Piotr Mordzak (diecezja łowicka).

Nagrodą za miejsce pierwsze i drugie była pielgrzymka do Ziemi Świętej. Kolejne miejsca finałowe uhonorowane zostały nagrodami pieniężnymi i upominkami książkowymi. Nagrody ufundowało Wydawnictwo Pallottinum oraz Dzieło Biblijne.

W dniu 2 czerwca 2019 r. odbył się egzamin licencjacki dla doktorantów INB KUL. Do egzaminu przystąpiły cztery osoby: Natalia Domka, Dzmitry Leuchyk, o. Jacek Pietrzak OP oraz ks. Mateusz Wyrzykowski. Egzamin dla wszystkich kandydatów zakończył się wynikiem pozytywnym.

W dniu 17 czerwea 2019 r. dyrektor Instytutu Nauk Biblijnych KUL ks. prof. dr hab. Mirosław S. Wróbel spotkał się w Watykanie z prof. Leonardo Sileo OFM, rektorem Papieskiego Uniwersytetu Urbaniana w celu omówienia i pogłębienia dalszej współpracy z Instytutem Nauk Biblijnych KUL. W rozmowach brał udział również o. prof. Andrzej Gieniusz CR, profesor Papieskiego Uniwersytetu Urbaniana.

W tym dniu doszło także do spotkania ks. prof. Mirosława S. Wróbla z prof. Henrym Pattarumadathilem SJ, dziekanem Wydziału Biblijnego Papieskiego Instytutu Biblijnego w Rzymie. Celem spotkania było prawne uregulowanie współpracy pomiędzy Biblicum i Instytutem Nauk Biblijnych KUL.

W dniu 20 września 2019 r. miała miejsce publiczna obrona doktoratów ks. lic. Valerego Martsinouskiego oraz ks. lic. Stanisława Sadowskiego. Ks. Martsinouski napisał doktorat o paranezie eschatologicznej w Pierwszym i Drugim 
Liście do Tesaloniczan. Tematem badań ks. Sadowskiego był udział św. Piotra w męce, śmierci i zmartwychwstaniu Chrystusa na podstawie J 18-21. Promotorem obu prac był ks. prof. dr hab. Henryk Witczyk. Obie obrony zakończyły się wynikiem pozytywnym.

W dniach 22-27 września 2019 r. w domu Ojców Zmartwychwstańców w Rzymie odbyło się spotkanie osób przygotowujących VI wydanie Biblii Tysiąclecia. Spotkanie prowadzili przedstawiciele Nida Institute, American Bible Society oraz profesorowie Papieskiego Uniwersytetu Urbaniana. W spotkaniu wzięli udział przedstawiciele Instytutu Nauk Biblijnych KUL: ks. prof. dr hab. Mirosław S. Wróbel, ks. prof. dr hab. Henryk Witczyk oraz dr hab. Krzysztof Mielcarek, prof. KUL.

\title{
III. Sympozja naukowe organizowane w Instytucie Nauk Biblijnych KUL
}

\author{
1. XIV Międzynarodowe Jesienne Dni Biblijne: „Rosa Twoja \\ jest rosq światłości, a ziemia wyda cienie zmarłych $(I z 26,19)$. \\ Zmartwychwstanie w Biblii i kulturze starożytnej basenu \\ Morza Śródziemnego", KUL, 23-24 października 2018 r.
}

„Tematem XIV Międzynarodowych Jesiennych Dni Biblijnych było zmartwychwstanie w Biblii oraz tradycjach pozabiblijnych, rozwijających się na obszarze starożytnego Egiptu, Mezopotamii, Izraela, Grecji oraz Rzymu. Poruszana tematyka dotyczyła aspektów historycznych, antropologiczno-kulturowych i teologicznych. Obejmowała również analizę konkretnych tekstów mówiących o zmartwychwstaniu. Podczas kolejnych sesji szukano odpowiedzi na pytania o kształt i charakter idei zmartwychwstania w tekstach i tradycjach pozabiblijnych, genezę i formę idei zmartwychwstania w starożytnym Izraelu, historyczność, szczególny charakter i status zmartwychwstania Chrystusa oraz jego wpływ na kształtowanie się teologii, moralności, eschatologii oraz eklezjologii chrześcijańskiej.

Wśród zaproszonych gości byli przedstawiciele zagranicznych ośrodków naukowych. Swoje wystąpienia mieli $\mathrm{m}$. in. Reimund Bieringer (Katholieke Universiteit Leuven, Belgia), Andrzej Gieniusz (Pontificia Università Urbaniana, Rzym, Włochy), Dominika Kurek-Chomycz (Liverpool Hope University, Liverpool, Wielka Brytania), Lukasz Popko (École biblique et archéologique française de Jérusalem, Izrael), Danuta Shanzer (Universität Wien, Wiedeń, Austria), Philip H. Towner (Nida Institute for Biblical Scholarship, Philadelphia, 
PA, USA), Nicholas Thomas Wright (University of St Andrews, St Andrews, Wielka Brytania).

Szczegółowy program XIV Międzynarodowych Jesiennych Dni Biblijnych przedstawiał się następująco:

Wtorek, 23 października

Sesja I. Listy Pawła

- Andrzej Gieniusz (Pontificia Università Urbaniana, Rzym, Włochy), „Jesus' Resurrection Appearances in 1 Cor 15,5-8 in the Light of the Expression $̋ \varphi \theta \eta+$ Dative Formula”.

- Reimund Bieringer (Katholieke Universiteit Leuven, Belgia), „«Clothed with our heavenly dwelling»: Building and Clothing Metaphors in the Resurrection Text in 2 Cor 4:16-5:10 in Light of the Situational Context of the Letter 9:30 Jason A Myers (Greensboro College, Greensboro, NC, USA), Resurrecting Obedience in Romans".

Sesja II. Nowe Stworzenie \& Łukaszowy Paweł

- Nicholas Thomas Wright (University of St Andrews, Wielka Brytania), „Resurrection and the Renewal of Creation”.

- Vadim Wittkowsky (Uniwersytet Humboldta, Berlin, Niemcy), „Paul's Resurrection in Acts 27-28? A Literary Comparison with Luke 23".

- Janusz Kucicki (Nanzan University, Nagoja, Japonia), „Witnesses of the Resurrected Messiah. Luke's Presentation of the Main Theological Theme of the Acts of the Apostles, with Particular Emphasis on the Narrative Regarding Paul's Missionary Activities".

Sesja III. Stary Testament

- Mary Jett (St. Francis College, Brooklyn Heights, NY, USA), „Resurrection and the Bones of Elisha (4 Reg 13:20-21/2 Kgs 13.20.21): The Text and Its Interpretations".

- Łukasz Popko (École biblique et archéologique française de Jérusalem, Izrael), „Mightier than Sheol: Why Paul Was Not Wrong While Quoting Hos 13:14".

- Ibolya Balla (Pápa Reformed Theological Seminary, Pápa, Węgry), „Resurrection and God's Kingship in Tobit 13: The Role of Tob 13:2 in Its Context".

Sesja IV. Ewangelie

- Nathanael Vette (University of Edinburgh, Wielka Brytania) - Will Robinson (Macquarie University, Sydney, Australia), „Was John the Baptist Raised From the Dead?: The Origins of Mk 6:14-29".

- Branislav Kluska (Katolicki Uniwersytet w Ružomberku, Słowacja), „Spatial Symbolism in the Resurrection Narratives of the Fourth Gospel”. 
Środa, 24 października

Sesja V. Nowy Testament \& Patrystyka

- Dominika Kurek-Chomycz (Liverpool Hope University, Wielka Brytania), "«God is not raising the dead, if he does not raise them up entire» (Tertullian, Res. 57.6): Resurrection and Disability in the New Testament and Other Early Christian Literature".

- Marcin Wysocki (KUL, Lublin), „ "Cui carni fuerit speranda inmortalitas» (Aug. Ep. 140, 12). The Incarnation of Christ and the Hope of Resurrection in the Latin Christian Letters of the 4th and 5th Century".

- Danuta Shanzer (Uniwersytet Wiedeński, Austria), „Resurrections before the Resurrection in the Imaginaire of Late Antiquity".

Sesja VI. List do Hebrajczyków \& 1 List Piotra

- Jaroslav Broz (Uniwersytet Karola, Praga, Czechy), „How the Hope on the « Heavenly Country» Influenced Anthropological Concept in the Epistle to the Hebrews?".

- Philip H. Towner (Nida Institute for Biblical Scholarship, Philadelphia, PA, USA), „Translating Resurrection in 1 Peter”.

Sesja VII. Od proroctw Starego Testamentu do 1 Listu do Koryntian (sesja w języku polskim)

- Andrzej Łukasz Jędrzejczak (Uniwersytet Adama Mickiewicza, Poznań), „Idee unicestwienia i zmartwychwstania w Apokalipsie Izajasza (Iz 24-27)”.

- Łukasz Krzyszczuk (Uniwersytet Wrocławski), „Interpretacja patrystyczna Oz 6,1-3".

- Stefan Szymik (KUL, Lublin), „Epikurejskie tło negacji zmartwychwstania umarłych w Koryncie (1 Kor 15)?”.

- Mariusz Szram (KUL, Lublin), „Jakie ciało nie odziedziczy Królestwa Bożego? Egzegeza patrystyczna 1 Kor 15,50".

Sesja VIII. Od Ewangelii do współczesnego Kościoła

- Charles Neff(Oklahoma City University, Oklahoma City, OK, USA), „Transformed: The Unrecognizable Jesus of the Post-Resurrection Accounts".

- Jaap Doedens (Pápa Reformed Theological Seminary, Pápa, Węgry), „«Like the Angels»: The Resurrection Sets the Agenda".

\section{Wiosenne Sympozjum Biblijne: „Mężczyznq i kobietq stworzył ich (Rdz 1,27). Płciowość w Biblii", KUL, 13 marca 2019 r.}

Podczas Wiosennego Sympozjum Biblijnego wygłoszonych zostało dziewięć referatów, a szczegółowy program przedstawiał się następująco: 
Sesja I:

- Waldemar Chrostowski (UKSW, Warszawa), „Stworzyt Bóg człowieka na swój obraz (Rdz 1,26). Ludzka cielesność i płciowość jako obraz Boży”.

- Barbara Strzałkowska (UKSW, Warszawa), „Rozporządzenia dotyczące sfery seksualnej człowieka w Księdze Kapłańskiej”.

Sesja II:

- Henryk Witczyk, „Boża wizja miłości mężczyzny i kobiety”.

- Artur Malina (UŚ, Katowice), „Jak aniołowie w niebie (Mk 12,25). Płeć, ciało i zmartwychwstanie".

- Stanisław Hałas SCJ (UPJPII, Kraków), „Ojcowska czy macierzyńska miłość Boga? Wybrane teksty biblijne".

- Zdzisław Żywica (UWM, Olsztyn), „Płciowość i czystość seksualna a przynależność do 144000 wykupionych z ziemi w świetle Ap 14,1-5".

Sesja III:

- Dariusz Kotecki (UMK, Toruń), „Symbolika seksualna w Ef 5,21-33”.

- Waldemar Szczerbiński (UAM, Poznań), „Judaizm wobec cielesności i seksualności człowieka".

- Marcin Kowalski (KUL), „Między darem Bożym, a konstruktem społecznym. Wczesnochrześcijańskie rozumienie płciowości na podstawie 1 Listu do Koryntian".

\section{Działalność naukowo-dydaktyczna pracowników Instytutu Nauk Biblijnych KUL}

Prezentację działalności naukowo-dydaktycznej rozpoczyna osoba dyrektora Instytutu Nauk Biblijnych KUL. W dalszej kolejności przyjęty został porządek alfabetyczny. Pod hasłem „Wykłady” należy rozumieć działalność dydaktyczną wykraczającą poza obowiązkowe zajęcia prowadzone przez pracowników Instytutu Nauk Biblijnych na Katolickim Uniwersytecie Lubelskim Jana Pawła II.

\section{Dyrektor Instytutu Nauk Biblijnych KUL ks. prof. dr hab. Mirosław Stanisław Wróbel}

\section{Monografia}

Targum Neofiti 1: Księga Wyjścia (Biblia Aramejska 2; Lublin: Wydawnictwo Gaudium 2019). 


\section{Artykuły naukowe}

1. „Jezus i chrześcijanie w Talmudzie”, Historia - Wiara - Nauka. Źródła poznania Jezusa Chrystusa (red. P. Artemiuk) (Biblioteka Teologii Fundamentalnej 13; Płock: Płocki Instytut Wydawniczy - Lublin: Stowarzyszenie Teologów Fundamentalnych w Polsce 2018) 167-184.

2. „Znaczenie targumów w argumentacji fundamentalnoteologicznej”, Historia - Wiara - Nauka. Źródła poznania Jezusa Chrystusa (red. P. Artemiuk) (Biblioteka Teologii Fundamentalnej 13; Płock: Płocki Instytut Wydawniczy - Lublin: Stowarzyszenie Teologów Fundamentalnych w Polsce 2018) 185-202.

3. „Tradycje targumiczne a Nowy Testament”, Zeszyty Naukowe Stowarzyszenia Biblistów Polskich 15 (2018) 403-413.

4. „The Influence of Isaiah on Jewish and Christian Liturgies”, The Unperceived Continuity of Isaiah (ed. J.H. Charlesworth) (London - New York: T\&TClark 2018) 186-201.

5. „ «Oto człowiek«: antropologia i teologia w procesie Jezusa przed Piłatem (J 18,28 - 19,16)”, ,,Czym jest czlowiek, że o nim pamiętasz?” (Ps 8,5). Antropologia w Piśmie Świętym (red. T. Bąk) (Analecta Biblica Lublinensia 16; Lublin: Wydawnictwo KUL 2019) 126-135.

6. „Znaczenie argumentacji Celsusa podważającej prawdę Pisma Świętego dla wczesnego chrześcijaństwa", Omnium Artifex Docuit Me Sapientia. Księga Pamiatkowa dla Księdza Doktora Stanisława Jankowskiego SDB w 75 rocznice urodzin (red. D. Sztuk) (Warszawa: Vocatio 2019) 252-261.

7. „Matka i Duch Święty jako Dar Ukrzyżowanej Miłości dla Kościoła”, ,Dla dobra Jego Ciała, którym jest Kościól” (Kol 1,24). Księga Pamiątkowa Księdza Profesora Antoniego Paciorka z okazji Złotego Jubileuszu Kapłaństwa (red. G.M. Baran) (Częstochowa: Edycja Świętego Pawła 2019) 491-503.

\section{Artykuły popularnonaukowe}

1. „Księga Amosa - nazwa, treść i orędzie teologiczne”, Krag Biblijny 36 (2018) 111-114.

2. „Powołanie i posłannictwo proroka Amosa (Am 7,12-17)”, Krag Biblijny 36 (2018) 114-118.

3. „Księga Jonasza - nazwa, treść i orędzie teologiczne”, Krag Biblijny 37 (2018) 127-130.

4. „Bóg pragnie ocalić wszystkie narody”, Krag Biblijny 37 (2018) 130-134.

5. „Księga Abdiasza - nazwa, treść i orędzie teologiczne”, Krąg Biblijny 38 (2018) 105-108. 
6. „Edom i jego mieszkańcy - geneza, historia i znaczenie”, Krag Biblijny 38 (2018) 108-112.

7. „Księga Micheasza - nazwa, treść i orędzie teologiczne”, Krąg Biblijny 39 (2019) 117-120.

8. „Mesjanizm proroka Micheasza w kontekście judaizmu okresu Drugiej Świątyni”, Krag Biblijny 39 (2019) 120-125.

9. „Ukrzyżowany Pan”, Apostoł Miłosierdzia Bożego 3 (103) (2019) 74-75.

10. „Księga Nahuma - nazwa, treść i orędzie teologiczne”, Krąg Biblijny 40 (2019) 159-162.

11. „Błogosławieństwo i przekleństwo w ujęciu biblijnym”, Krag Biblijny 40 (2019) 162-167.

12. „Śmierć Jezusa na krzyżu”, Apostoł Miłosierdzia Bożego 4(104) (2019) 48-49.

\section{Sympozja}

1. Organizacja i uczestnictwo w XIV Międzynarodowych Jesiennych Dniach Biblijnych „Zmartwychwstanie w Biblii i tradycjach pozabiblijnych” (KUL, Lublin, 23-24.10.2018).

2. Wykład „Eschatologia św. Łukasza”, Szkoła Biblijna: „Orędzie i myśl św. Łukasza”, (Uniwersytet Szczeciński, Szczecin, 17.11.2018).

3. Referat „Eschatologia targumów” i udział w konferencji „Eschatologia pism literatury międzytestamentalnej" (Uniwersytet w Presovie, Słowacja, 6-7.03.2019).

4. Referat „Maryja na kartach biblijnych jako wzór kobiecości”, V Sympozjum z cyklu: Duchowość Ziemi Świętej (Lublin, KUL, 28.05.2019).

5. Wygłoszenie laudacji dla projektu Biblia Audio, uroczysta gala wręczenia nagrody im. Włodzimierza Pietrzaka (Warszawa, Zamek Królewski, 6.06.2019).

6. Referat „The Personal Dimension of Targumic Memra and Johannine Logos", International Congress of Personalism (Israel, Domus Galilaeae, 12 16.08.2019).

7. Udział i przewodniczenie w panelu dyskusyjnym, 57. Sympozjum Biblistów Polskich (Wigry, 16-18.09.2019).

\section{Działalność organizacyjna na rzecz KUL}

Organizacja i udział w podpisaniu długoterminowej umowy o współpracy pomiędzy Katolickim Uniwersytetem Lubelskim Jana Pawła II a Seminarium w Orchard Lake (USA) (KUL, Lublin, 27.02.2019). 


\section{Szkolenia i staże}

1. Staż w École Biblique w Jerozolimie. Redakcja monografii Targumy między Starym a Nowym Testamentem (16.08 - 12.09.2019).

2. Udział w warsztatach naukowych i spotkaniu thumaczy VI wydania Biblii Tysiąclecia (Papieski Uniwersytet Urbaniana, Watykan, 23-26.09.2019).

\section{Recenzje prac doktorskich}

1. Williams Peter Awoshiri, Towards a Servant Model of Leadership: A Socio-Rhetorical Investigation of the Johannine Farewell Discourse (John 13-17) (Warsaw 2018).

2. Ks. Tomasz Borkowski, Jezus jako Mistrz (epista,thj) w Ewangelii wedtug św. Łukasza (Warszawa 2018).

3. Ks. Marek Kowalczuk, Koncepcja szczęścia ludzkiego w šîrę hamma ălôt (Ps 120 - 134) (Warszawa 2019).

4. Jerzy Bosowski, Wyrocznie przeciw Egiptowi Ez 29-32 w świetle retoryki hebrajskiej (Opole 2019).

\section{Recenzje wydawnicze książek}

1. P. Podeszwa - W. Szczerbiński (red.), Izrael - od marzenia do spetnienia, Israel - from a dream to a dream come true (Poznań - Gniezno: Gaudentinum 2018).

2. J.B. Łach (red.), Księgi Ludu Bożego Starego Przymierza: Tora - Nebi'im Ketubim. Ujęcie syntetyczno-teologiczne (Pismo Święte Starego Testamentu 12/3; Poznań: Pallottinum) 2018.

3. K. Wojciechowska - M. Rosik, Mądrość zstępująca z góry. Komentarz strukturalny do Listu św. Jakuba (Warszawa: Wydawnictwo Naukowe Chrześcijańskiej Akademii Teologicznej 2018).

4. R. Jasnos - M. Baraniak - A. Mrozek (red.), W kręgu dyskursów biblijnych. Różne wymiary identyfikacji w ujęciu kulturowym i edukacyjnym ( CulturaSpiritualitas - Educatio 2; Kraków: Wydawnictwo Naukowe Akademii Ignatianum 2018).

5. M. Terka - J. Kapuściński - Ł. Laskowski (red.), Księga Jubileuszowa J.E. Abp. Dr. Stanisława Nowaka (Veritati et Caritati 10; Częstochowa: Wydawnictwo Naukowe Wyższego Instytutu Teologicznego 2018).

6. M. Jasiński, Józef-pierworodny Izraela w toledot Jakuba (Rdz 37-50) (Warszawa: Bernardinum 2019). 


\section{Działania popularyzujące Biblię}

1. Cykl konferencji biblijnych: Rola Ducha Świętego w życiu Kościoła (Ognisko Światła i Miłości, Kaliszany, 20-21.10.2018).

2. Organizacja i prowadzenie: Niedziela Słowa Bożego (parafia św. Barbary, Łęczna, 28.10.2018).

3. Cyk1 konferencji dla kapłanów: Apostoł Piotr w drodze do świętości (Ognisko Światła i Miłości, Kaliszany, 19-22.11.2018).

4. Cykl referatów: Magnificat w sercu Matki Boga, Spotkanie biblijne: „W skarbcu biblijnej mądrości” (Dom Rekolekcyjny „Promien”” Sióstr Służek Maryi Niepokalanej, Nałęczów, 11-13.01.2019).

5. Cykl konferencji: Eucharystia - Pełnią Życia Chrześcijańskiego (Ognisko Światła i Miłości, Kaliszany, 23-24.03.2019).

6. Cykl referatów: Maryja - Matka Boga i Matka człowieka, Spotkanie Biblijne: „W skarbcu biblijnej mądrości” (Dom Rekolekcyjny „Promień” Sióstr Służek Maryi Niepokalanej, Nałęczów, 17-19.05.2019).

7. Cykl konferencji: Obrazy Eucharystii w Starym Testamencie (Ognisko Światła i Miłości, Kaliszany, 8-9.06.2019).

\section{Ks. dr Tomasz Bąk}

\section{Książka pod redakcją}

„Czym jest czlowiek, że o nim pamiętasz?” (Ps 8,5). Antropologia w Piśmie Świętym (Analecta Biblica Lublinensia 16; Lublin: Wydawnictwo KUL 2019).

\section{Artykuły naukowe i sprawozdania}

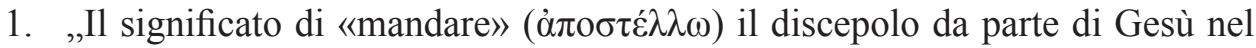
Vangelo di Marco. Parte II: Pericopi del Vangelo di Marco con il verbo

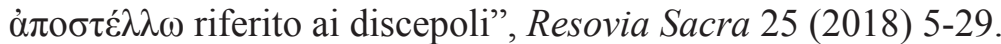

2. „A Critical Edition and Philological Analysis of the First Chapter of Deutero-Isaiah (Isa 40) on the Basis of the Coptic Manuscript sa 52 (M 568) in Light of Other Coptic Manuscripts Written in the Sahidic Dialect and the Greek Text of the Septuagint", The Biblical Annals 9/1 (2019) 73-100.

3. Sprawozdanie: „Działalność Instytutu Nauk Biblijnych w roku akademickim 2017/2018", The Biblical Annals 9/1 (2019) 237-268. 


\section{Sympozja}

1. Referat „Nad Jego Prawem rozmyśla dniem i noca (Ps 1,2). Obraz człowieka szczęśliwego w Psalmie 1", IV Sympozjum im. O. Augustyna Jankowskiego „Psalmy - poezja czy modlitwa?” (Tyniec, 6.11.2018).

2. Referat „Eschatologiczna przemiana kosmosu w Liście do Rzymian (Rz 8,19-22)”, konferencja międzynarodowa „Eschatologia v Biblii a Targumickej Tradicii”" (Preszów, Słowacja, 06.03.2019).

3. Członkostwo w Radzie Naukowej Ogólnopolskiej interdyscyplinarnej studencko-doktoranckiej konferencji naukowej „Zapachy starożytności” (Lublin, 17.05.2019).

\section{Recenzje wydawnicze}

Anonimowe recenzje wydawnicze trzech artykułów naukowych do czasopisma Studia Gdańskie.

\section{Kwerenda}

Kwerenda biblioteczna w Bibliotece Papieskiego Uniwersytetu Biblijnego (Biblicum) (Rzym, 31.05-10.06 2019).

\section{Kierowanie i realizacja projektu}

Realizacja grantu wewnątrzwydziałowego: „Edycja manuskryptu koptyjskiego" (październik 2018 - październik 2019).

\section{Działalność dydaktyczna}

1. Odczyt „Odrzucenie czy powołanie? Wyznanie Piotra pod Cezareą Filipową. Analiza egzegetyczno-teologiczna Mk 8,27-30" (Wyższe Seminarium Duchowne w Lowiczu, 19.11.2018).

2. Odczyt „Syn człowieczy musi wiele wycierpieć. Analiza egzegetycznoteologiczna Mk 8,31-33" (Wyższe Seminarium Duchowne w Łowiczu, 19.11.2018).

3. Odczyt ,Znaczenie greckiego czasownika epitimaō w kontekście Ewangelii według św. Marka" (Wyższe Seminarium Duchowne w Łowiczu, 19.11.2018).

4. Odczyt „Przypowieść o miłosiernym Samarytaninie. Analiza egzegetyczno-teologiczna w kontekście Ewangelii według św. Łukasza” (Instytut Teologiczno-Pastoralny w Rzeszowie, 01.12.2018). 
5. Odczyt „Tryptyk o Bożym Miłosierdziu. Analiza egzegetyczno-teologiczna Łk 15" (Instytut Teologiczno-Pastoralny w Rzeszowie, 15.12.2018).

6. Wykłady „Egzegeza Starego Testamentu: Pięcioksiąg” (Wyższe Seminarium Duchowne w Rzeszowie, rok IV, semestr I, rok akademicki 2018/2019) (45 godzin);

7. Wykłady „Historia Starego Testamentu” (Studia Podyplomowe Katechetyczno-Teologiczne, Instytut Teologiczno-Pastoralny w Rzeszowie, semestr I, rok akademicki 2018/2019).

8. Wykłady „Egzegeza Nowego Testamentu: Pisma Pawłowe” (Wyższe Seminarium Duchowne w Rzeszowie, rok III, semestr II; rok akademicki 2018/2019) (45 godzin).

9. Wykłady „Archeologia i geografia biblijna” (Wyższe Seminarium Duchowne w Rzeszowie, rok I, semestr II; rok akademicki 2018/2019) (15 godzin).

10. Odczyt „Pierwszy i Drugi List do Tesaloniczan. Analiza egzegetyczna i teologiczna wybranych zagadnień" (Instytut Teologiczno-Pastoralny w Rzeszowie, Diecezjalne Studium Biblijne, 23.03.2019).

11. Wykłady „Historia Starego Testamentu - księgi historyczne” (Studia Podyplomowe Katechetyczno-Teologiczne, Instytut Teologiczno-Pastoralny w Rzeszowie, semestr II, rok akademicki 2018/2019).

12. Odczyt „Analiza egzegetyczna i wymowa teologiczna Listu do Rzymian” (Instytut Teologiczno-Pastoralny w Rzeszowie, 15.06.2019).

\section{Działania popularyzujące Biblię}

1. Audycja w Katolickim Radiu VIA na temat biblijnej genezy Święta Objawienia Pańskiego (Rzeszów, 06.01.2019).

2. Audycja w Katolickim Radiu VIA na temat rozumienia miłości w świetle Pisma Świętego (Rzeszów, 09.02.2019).

3. Audycja w Katolickim Radiu VIA na temat rozumienia wydarzeń wielkoczwartkowych w świetle Słowa Bożego (Rzeszów, 18.04.2019).

4. Audycja w Katolickim Radiu VIA na temat rozumienia wydarzeń wielkopiątkowych w świetle Słowa Bożego (Rzeszów, 19.04.2019).

5. Audycja w Katolickim Radiu VIA na temat rozumienia wydarzeń wielkosobotnich w świetle Słowa Bożego (Rzeszów, 20.04.2019).

6. Audycja w Katolickim Radiu VIA na temat rozumienia Uroczystości Zmartwychwstania Pańskiego w świetle Słowa Bożego (Rzeszów, 21.04.2019). 


\section{Ks. dr hab. Henryk Drawnel SDB, prof. KUL}

\section{Artykuły naukowe}

1. „An Introductory Bibliography for the Study of 1 Enoch”, The Biblical Annals 9/1 (2019) 101-130.

2. "Qumran and the Ancient Near East", T\&T Clark Companion to the Dead Sea Scrolls (red. G.J. Brooke - Ch. Hempel) (London: Bloomsbury T\&T Clark 2019) 109-118.

3. „Aramaic Levi Document”, T\&T Clark Encyclopedia of Second Temple Judaism (red. L.T. Stuckenbruck - D.M. Gurtner) (London: Bloomsbury 2019) I, 106-109.

4. „Astronomy and Astrology”, T\&T Clark Encyclopedia of Second Temple Judaism (red. L.T. Stuckenbruck - D.M. Gurtner) (London: Bloomsbury 2019) II, 88-90.

5. „Fallen Angels”, T\&T Clark Encyclopedia of Second Temple Judaism (red. L.T. Stuckenbruck - D.M. Gurtner) (London: Bloomsbury 2019) II, 265-267.

6. „Aramaic Enoch: The Book of Dreams”, The Textual History of the Bible. II. The Deuterocanonical Scriptures. B. Baruch/Jeremiach, Daniel (Additions), Ecclesiasticus/Ben Sira, Enoch, Esther (Additions), Ezra (red. F. Feder M. Henze) (Leiden: Brill 2019) 342-348.

\section{Sympozja}

Referat „New Paleographic Readings in the Manchester Manuscript of the Visions of Levi", International Conference of the Society of Biblical Literature (Gregorian University and Pontifical Biblical Institute, Rome, 1-5.07.2019).

\section{Recenzje wydawnicze}

Anonimowe recenzje wydawnicze czterech artykułów naukowych do czasopism: Dead Sea Discoveries (Wydawnictwo Brill) i Seminare.

\section{Recenzja w przewodzie habilitacyjnym}

Recenzja w postępowaniu habilitacyjnym ks. dr. Adama Kubisia (Wydział Teologii KUL, Lublin, 8.05.2019). 


\section{Kwerenda naukowa i wyjazd studyjny}

1. Kwerenda naukowa w bibliotece Saulchor w Paryżu oraz badanie archiwum prof. J.T. Milika (Paryż, 11-17.11.2018).

2. Praca nad aramejskim manuskryptem P1185 z Genizy Kairskiej (University of Manchester Library, John Rylands Library, Great Britain, 1-5.04.2019).

\section{Działalność dydaktyczna}

Wykład „Życie dusz po śmierci według rozdziału 22 Pierwszej Księgi Henocha" (klasztor oo. Dominikanów, Lublin, 25.11.2018).

\section{Ks. dr hab. Dariusz Dziadosz}

\section{Monografie}

1. Księga Sędziów. Rozdziały 1-5. Wstęp - Przekład z oryginału-Komentarz (Nowy komentarz biblijny. Stary Testament 7/1; Częstochowa: Edycja Świętego Pawła 2019).

2. Księga Sędziów. Rozdziały 6-12. Wstęp-Przekład z oryginatu-Komentarz (Nowy komentarz biblijny. Stary Testament 7/1; Częstochowa: Edycja Świętego Pawła 2019).

\section{Artykuły naukowe i recenzje}

1. „Biblia - księgą życia, prawa i przymierza”, Ethos 31/3 (2018) 21-44.

2. „«Izraelici czynili to, co złe w oczach Pana» (Sdz 2,11). Teologiczne aspekty upadku w Księdze Sędziów", Ethos 31/4 (2018) 21-49.

3. "The Spirit of YHWH as the Charism of the Pre-Monarchic Liberators of Israel and the Theological Symbol of God's Salvific Activity in the Book of Judges", Biblica et Patristica Thoruniensia 11/4 (2018) 463-493.

4. „The Circumcision of the Heart as a Deuteronomic Metaphor of Religious Identity of an Israelite", Biblica et Patristica Thoruniensia 12/2 (2019) 159-189.

5. Recenzja: Isaak Kalimi, Starożytny historyk Izraelski. Studium o Kronikarzu, jego epoce, miejscu działalności i dziele (Kraków: Zakład Wydawniczy Nomos 2016), The Biblical Annals 9/2 (2019) 421-426. 


\section{Promotor prac magisterskich}

1. Tomasz Piróg, Źródła i przejawy pobożności Tobiasza. Analiza egzegetyczno-teologiczna Tb 1,3-2,14 (KUL, Lublin 2019).

2. Maciej Pawlik, Deuteronomistyczna koncepcja pobytu Izraelitów na wygnaniu. Studium egzegetyczno-teologiczne Jr 29,1-32 (KUL, Lublin 2019).

3. Waldemar Wawrzyszko, Stowo Boże w duchowej i duszpasterskiej formacji kapłana. Studium analityczno-porównawcze wybranych tekstów Rozmyślań o życiu kapłańskim św. bpa Józefa Sebastiana Pelczara (KUL, Lublin 2019).

4. Agnieszka Wawrzyszko, Boska ciemność przestrzenia objawiajacego się Pana. Teologiczna recepcja Wj 19,1-24,18 w Teologii mistycznej PseudoDionizego Areopagity (KUL, Lublin 2019).

\section{Sympozja}

1. Organizacja Wiosennych Dni Biblijnych na KUL Jana Pawła II pod hasłem: „Mężczyzna i kobieta stworzyt ich (Rdz 1,27). Płciowość w Biblii” (KUL, Lublin, 13.03.2019).

2. Referat „Pomiędzy historią, ideologią i teologią. Pro-dawidowa lektura tradycji o Saulu w 1Kronik”, XIII Ogólnopolska Konferencja Naukowa „Interpretacja Pisma Świętego. Pierwsza i Druga Księga Kronik - orędzie, interpretacja i recepcja" (Instytut Nauk Biblijnych, UKSW, Warszawa, 14.05.2019).

3. Referat „Słowo Biblii prawdą o Bogu, człowieku i świecie”, krajowej konferencji naukowej: „Poznacie prawdę a prawda was wyzwoli (J 8,32)” (Arena Sanok, 15.06.2019).

\section{Recenzja w przewodzie habilitacyjnym}

Funkcja recenzenta Komisji habilitacyjnej w procesie nadania stopnia naukowego doktora habilitowanego dla dr. Marcina Majewskiego (5.02.2019 30.05.2019).

\section{Działalność statutowa na rzecz KUL}

Promocja Katolickiego Uniwersytetu Lubelskiego Jana Pawła II na olimpiadach i szkoleniach katechetycznych i biblijnych w archidiecezji przemyskiej w latach 2018-2019 (2 wystąpienia). 


\section{Współpraca międzynarodowa}

Seminarium naukowe - promotorstwo pracy doktorskiej z nauk biblijnych na Pontificio Istituto Biblico w Rzymie (20 godzin w latach 2018-2019).

\section{Ks. dr hab. Marcin Kowalski}

\section{Osiągnięcia naukowe}

Uzyskanie stopnia naukowego doktora habilitowanego na podstawie cyklu publikacji zatytułowanego „Usprawiedliwienie, dar nowego życia i Duch. Grecko-rzymski i żydowski charakter argumentacji Pawła w lekturze socjoretorycznej Rz 1-8" (KUL, Lublin, 15.01.2019).

\section{Monografia}

P. Śliwiński - M. Kowalski, Jutro Niedziela (Kraków: Stacja7.p1 2019).

\section{Artykuły naukowe i recenzje}

1. „The Brokerage of the Spirit in Romans 8", Catholic Biblical Quarterly 80/4 (2018) 636-654.

2. Recenzja: Stanley E. Porter - Christopher D. Land, Paul and His Social Relations (Pauline Studies 7; Leiden - Boston: Brill 2013), The Biblical Annals 8/4 (2018) 639-644.

3. „Rhetoric in the Service of the Gospel in Inesperto nell'arte di parlare (2 Cor 11,6) by A. M. Gieniusz, CR", The Biblical Annals 9/1 (2019) 191-212.

4. Recenzja: Reimund Bieringer - Emmanuel Nathan - Didier Pollefeyt - Peter J. Tomson (eds.), Second Corinthians in the Perspective of Late Second Temple Judaism (Compendia Rerum Iudaicarum ad Novum Testamentum 14; Leiden: Brill 2014), The Biblical Annals 9/3 (2019) 601-608.

5. Rozdział w monografii: „Nowe życie i Duch pośrednik w Rz 5-8. Lektura socjoretoryczna", Idźcie i głoście nowe życie w Chrystusie (red. W. Chrostowski - J. Kręcidło - W. Linke) (Nowe Studia z Biblistyki 1[10]; Warszawa: Wydawnictwo Naukowe UKSW) 177-218.

\section{Promotor pomocniczy pracy doktorskiej}

Stanisław Sadowski, Udział św. Piotra w męce, śmierci i zmartwychwstaniu Chrystusa na podstawie J 18-21 (KUL, wrzesień 2019). 


\section{Sympozja}

1. Udział w sympozjum ogólnopolskim i wygłoszenie referatu „Stoicka pneuma a Pawłowa koncepcja Ducha w Rz 8", 56. Sympozjum Biblistów Polskich (Łomża, 18.09.2018).

2. Udział w krajowej sesji naukowej i wygłoszenie referatu „Biblijne podłoże nauki o małżeństwie w Humanae Vitae i Amoris Laetitia”, Sesja „Od Humanae Vitae do Amoris Laetitia" (Wyższe Seminarium Duchowne, Kielce 19.11.2018).

3. Organizacja wspólnie z Pontificia Università Urbaniana oraz Nida Institute międzynarodowego seminarium translatorskiego poświęconego rewizji i VI wydaniu Biblii Tysiąclecia (Rzym, 24-29.09.2019).

4. Współorganizacja 14th International Biblical Congress, „For Your Dew Is a Dew of Light, and the Earth Will Give Birth to Her Dead (Isa. 26:19). Resurrection in the Bible and Ancient Mediterranean World" (KUL, 23-24.10.2018).

5. Udział w sympozjum krajowym i prowadzenie sesji: 51. Tydzień Eklezjologiczny „Młodzi w Kościele” (KUL, Lublin, 25-28.02.2019).

6. Udział w sympozjum ogólnopolskim i wygłoszenie referatu „Między darem Bożym a konstruktem społecznym. Wczesnochrześcijańskie rozumienie płciowości na podstawie 1 Listu do Koryntian”, Wiosenne Dni Biblijne „Mężczyzną i kobietą stworzył ich” (KUL, Lublin 13.03.2019).

7. Udział w sympozjum międzynarodowym i wygłoszenie referatu „Duch zmartwychwstania u Pawła i jego ślady w tradycji grecko-rzymskiej i żydowskiej”, Międzynarodowe Sympozjum „Eschatologia v Biblii a Targumickej Tradicii" (Grekokatolicki Wydział Teologiczny Uniwersytetu w Preszowie, Słowacja, 05-06.03.2019).

8. Udział w sympozjum międzynarodowym i wygłoszenie referatu „The Cognitive Spirit and the Gift of New Life in Romans 8. The Novelty of Paul's Thought in Comparison to the Greco-Roman and Jewish Concepts of Pneuma", The Society of Biblical Literature International Meeting (Rome, Italy, 01-05.07.2019).

\section{Kierowanie i realizacja projektów}

1. Kierowanie wraz z o. prof. A. Gieniuszem CR grupą Nowego Testamentu w projekcie rewizji i VI Wydania Biblii Tysiąclecia, organizacja seminariów translatorskich (Rzym. 2017-2019).

2. Realizacja dwóch grantów naukowych w ramach projektu „Filozofia i teologia w kontekście współczesnych przemian nauki” - Regionalna Inicjatywa Doskonałości na wyjazdy zagraniczne i publikację artykułów w wysoko punktowanych czasopismach naukowych (marzec i czerwiec 2019). 
3. Realizacja grantu wewnątrzwydziałowego na tłumaczenie i publikację dwóch artykułów w wysoko punktowanych czasopismach naukowych (październik 2018 - październik 2019).

4. Realizacja grantu wspólnie z UPJP II, Kraków „Metodologiczna odnowa teologii dogmatycznej”, NCN nr 2017/27/B/HS1/01634, opracowywane zagadnienie ,, Separacja - tak, rozwód - nie. Wyzwania i implikacje płynące z metodologicznego rozwoju nauk biblijnych i teologii systematycznej" (październik 2018 - październik 2020).

\section{Działalność dydaktyczna}

1. Wykłady dla katechetów w ramach studium podyplomowego KUL: „Prorocy” (WSD Kielce, październik 2018 - styczeń 2019).

2. Wykłady dla sióstr karmelitanek: Pięcioksiąg, Księga Liczb (październik 2018 - czerwiec 2019).

3. Cykl wykładów The Stories of Patriarchs (Genesis 12-37): „Abraham, Our Father in Faith (Gen 12-22)", „Isaac, the One who Brings Blessing and Peace (Gen 25-26)”, „Jacob, the One Who Fought with God (Gen 27-37)” (Elizabeth Ann Seton, Shrub Oak, NY, USA, sierpień 2019).

\section{Działania popularyzujące Biblię}

1. Telewizyjny Uniwersytet Biblijny (TV Trwam) - cykl wykładów na temat Księgi Liczb i Księgi Powtórzonego Prawa (październik 2018 - czerwiec 2019).

2. Seria programów TV „Słowo Życia” (TV Trwam, październik 2018 - czerwiec 2019).

3. Programy radiowe „Rozmowy niedokończone” i „Szukając Słowa Bożego” (Radio Maryja, październik 2018 - czerwiec 2019).

4. Program w TVP Info poświęcony Niedzieli i Tygodniowi Biblijnemu 2019 (Warszawa, 28.04.2019).

\section{Ks. dr hab. Adam Kubiś}

\section{Osiągnięcia naukowe}

Uzyskanie stopnia naukowego doktora habilitowanego na podstawie cyklu publikacji zatytułowanego „Jezus Chrystus - Objawiciel uobecniający Boga pośród ludu Przymierza. Intertekstualność kluczem chrystologii Ewangelii Janowej" (KUL, Lublin, 14.05.2019). 


\section{Artykuły naukowe i recenzje}

1. „Interpretacja pokutna Janowego opisu obmycia stóp uczniom przez Jezusa. Cz. 1: Interpretacje sakramentalne na tle współczesnych wyjaśnień J 13,120", The Biblical Annals 8/3 (2018) 379-420.

2. „Interpretacja pokutna Janowego opisu obmycia stóp uczniom przez Jezusa. Cz. 2: Argument odwołujący się do antropologii kulturowej”, The Biblical Annals 8/4 (2018) 567-586.

3. „Temat stworzenia w Ewangelii Janowej”, Collectanea Theologica 88/3 (2018) 5-38.

4. „Metafora Oblubieńcza w Ewangelii Janowej. Część 1. Oblubieniec spotyka Oblubienicę (J 1-4)", Studia Gdańskie 42 (2018) 39-65.

5. „Metafora Oblubieńcza w Ewangelii Janowej. Część 2. Mesjańskie zaślubiny (J 12-20)", Studia Gdańskie 43 (2018) 39-59.

6. „The Old Testament Background of "Ecce Homo" in John 19:5”, Biblica et Patristica Thorunensia 11/4 (2018) 495-519.

7. „Morderczy gniew. Intertekstualna lektura Mt 5,21-22”, Verbum Vitae 34 (2018) 249-287.

8. „Judas, Disciples or Jesus' Word? A Mysterious Reference to «the Scripture» in John 17,12", The Biblical Annals 9/1 (2019) 131-176.

9. „Wytyczne dla autorów INB KUL. IBS KUL Instructions for Contributors”, S. Bazyliński, Wprowadzenie do studium Pisma Świętego wyd. 2, uzupełnione i poszerzone (Kielce: Jedność 2019) 320-326.

10. Recenzja: Steven D. Anderson - A.D. Riddle - Todd Bolen, Photo Companion to the Bible. The Gospels. I. Matthew. II. Mark. III. Luke. IV. John (www.BiblePlaces.com 2017), Verbum Vitae 34 (2018) 495-497.

11. Recenzja: Scott Hahn, Czwarty Kielich. Odkrywanie tajemnicy Ostatniej Wieczerzy i krzyża (Kraków: Espirt 2019), Verbum Vitae 35 (2019) 539-544.

12. Recenzja: Marcin Mój, Kompozycje warstwowe w Ewangelii Marka (Attende Lectioni. Series Nova 1; Tarnów: Biblos 2018), Verbum Vitae 35 (2019) 555-559.

\section{Sympozjum}

Referat „Starotestamentalne tło Piłatowego Ecce homo w J 19,5”, 57. Sympozjum Biblistów Polskich (Wigry, 17.09.2019). 


\section{Promotor pracy magisterskiej}

Kamil Bambrowicz, Funkcja cytatów starotestamentowych w Janowym opisie śmierci Jezusa. Studium literacko-intertekstualne J 19,28-37 (WSD Rzeszów - UPJP II, Kraków 2019).

\section{Recenzje prac magisterskich (Master of Arts)}

1. Jeffrey J. Przewozniak, The Postmodern Condition: History, Diagnosis, and Solutions (SS. Cyril and Methodius Seminary, Orchard Lake, MI, USA, 24.04.2019).

2. Adrian Frąckowiak, Catholic and Muslim Morality: Comparison and Contrast (SS. Cyril and Methodius Seminary, Orchard Lake, MI, USA, 25.04.2019).

\section{Kwerendy}

1. École biblique et archéologique française de Jérusalem (Jerozolima, Izrael, 20.12.2018-4.01.2019).

2. Adam Cardinal Maida Alumni Library (Orchard Lake, Michigan, USA, $19.01-19.05 .2019)$.

3. École biblique et archéologique française de Jérusalem (Jerozolima, Izrael, $4.07-7.09 .2019)$.

\section{Działalność organizacyjna}

1. Współorganizacja 14th International Biblical Congress, „For Your Dew Is a Dew of Light, and the Earth Will Give Birth to Her Dead (Isa. 26:19). Resurrection in the Bible and Ancient Mediterranean World" (KUL, 2324.10.2018).

2. Organizacja i współprowadzenie warsztatów archeologiczno-historyczno-biblijnych „Abraham” w ramach projektu Szkoła Dabar (Izrael - Palestyna, 17-22.08.2019).

3. Organizacja i współprowadzenie warsztatów archeologiczno-historyczno-biblijnych „Dawid” w ramach projektu Szkoła Dabar (Izrael - Palestyna, 24-29.08.2019). 


\section{Współpraca międzynarodowa}

Visiting Professor w SS. Cyril \& Methodius Seminary w Orchard Lake, MI, USA. Dwa cykle wykładów: Pauline Literature and New Testament Epistles $(45$ h) oraz Wisdom Literature and Psalms (45 h) (19.01 - 4.05.2019).

\section{Działalność dydaktyczna}

1. Wykład „Biblijna historia zbawienia”, WSD Rzeszów (15 godzin).

2. Wykład „Ewangelie synoptyczne”, WSD Rzeszów (45 godzin).

3. Wykład „Wisdom Literature and Psalms”, SS. Cyril \& Methodius Seminary, Orchard Lake, MI, USA (42 godziny).

4. Wykład "Pauline Literature and the New Testament Epistles", SS. Cyril \& Methodius Seminary, Orchard Lake, MI, USA (42 godziny).

\section{Działania popularyzujące Biblię}

1. Seria dziesięciu wykładów na temat pierwszej części Dziejów Apostolskich (Dz 1-12) (Dom Diecezjalny „Tabor”, Rzeszów, 24-27.10.2018).

2. Seria wykładów "Scriptural Roots of the Catholic Marian Devotion”: „The New Eve”, „The New Ark”, „The Queen Mother” (Orchard Lake, MI, USA, 3-5.04.2019).

3. Warsztaty biblijne dla diakonów diecezji rzeszowskiej w Ziemi Świętej (Izrael, 25.06-3.07.2019).

\section{Dr hab. Krzysztof Mielcarek, prof. KUL}

\section{Artykuł naukowy i recenzja}

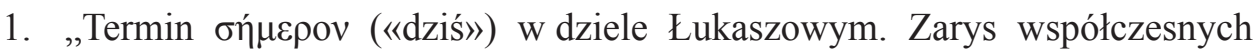
badań", Verbum Vitae 35 (2019) 217-244.

2. Recenzja: Candida R. Moss - Joel S. Baden, Reconceiving Infertility: Biblical Perspectives on Procreation and Childlessness (Princeton, NJ: Princeton University Press 2015), The Biblical Annals 9/1 (2019) 221-226.

\section{Artykuły popularnonaukowe}

1. "Literatura mądrościowa w Biblii Hebrajskiej i Greckiej - wprowadzenie. Część II/9”, Krag Biblijny 37 (2018) 121-126. 
2. „Literatura mądrościowa w Biblii Hebrajskiej i Greckiej - wprowadzenie. Część II/10", Krąg Biblijny 38 (2018) 97-103.

3. „Historia zbawienia. Wydarzenia historii zbawienia. II/10. Stary Testament, Literatura Apokaliptyczna", Krag Biblijny 39 (2019) 109-115.

4. „Historia zbawienia. Wydarzenia historii zbawienia. II/1. Nowy Testament, Jezus Chrystus - osoba i dzieło Zbawiciela", Krag Biblijny 40 (2019) 151-157.

\section{Sympozja}

1. Seminario per studiosi di Sacra Scrittura [21-25 Gennaio 2019], «L'opera lucana (Vangelo di Luca e Atti degli Apostoli)» (Pontificio Istituto Biblico, Roma, Italia, 21-25.01.2019).

2. Referat „Uwierzyli Pismu i Słowu, które im Pan powiedziat (J 2,22c). Przekład polski Biblii Ekumenicznej 1993-2017”, 51. Tydzień Eklezjologiczny „Młodzi w Kościele”, (KUL, Lublin, 28-30.02.2019).

3. Referat „Ministry In The Church, A Catholic reading of some ecclesial aspects” wygłoszony podczas „The Church: Towards a Common Vision”, Faith and Order Consultation on "Towards a Global Vision of the Church" (Faculdade Unida de Vitoria, Vitória/ES, Brazil, 20-23.03.2019).

4. Referat „Gathered reflections on Ecclesiological Matters from the Global South - the case study of African Churches", Faith and Order Committee on "Towards a Global Vision of the Church" (Nanjin, China, 14-19.06.2019).

5. Wystąpienie w ramach zjazdu przewodników katolickich po Ziemi Świętej na temat znaczenia geografii zbawienia (Warszawa, 6.09.2019).

\section{Promocje prac magisterskich}

1. Adam Policha OP, Kościót i jego przeciwnicy w metaforze dwóch Świadków (Ap 11, 3-13). Studium egzegetyczno-teologiczne (Kraków 2019).

2. Szymon Majewski, Stużba braciom i miłosierdzie wobec , matych” droga ucznia Chrystusa (Mk 9,33-37). Studium egzegetyczno-teologiczne (Lublin 2019).

3. Artur Juszczak, Motyw ucznia w mowie pożegnalnej Jezusa Łk 22,21-38. Studium egzegetyczno-teologiczne (Lublin 2019).

\section{Szkolenia}

1. Nanovic Institute, Mendoza College of Business, Notre Dame University, South Bend, Indiana USA: Program for Catholic Leadership (13-21.07.2019).

2. Seminarium translatorskie organizowanego przez NIDA INSTITUTE (USA) i Uniwersytet Urbaniana (Rzym, 23-28.09.2017). 


\section{Kwerenda}

École biblique et archéologique française de Jérusalem (Jerozolima, Izrael, luty 2018).

\section{Udział w komisjach}

1. Recenzent w komisji ds. postępowania habilitacyjnego ks. dr. Janusza Kucickiego (Wydział Teologii KUL, 17.12.2018).

2. Sekretarz w komisji ds. postępowania habilitacyjnego ks. dr. Marcina Kowalskiego (Wydział Teologii KUL, 13.01.2019).

\section{Działalność organizacyjna}

1. Koordynator instytutowy programu Erasmus + .

2. Kurator Koła Naukowego Teologów KUL.

\section{Działalność dydaktyczna}

1. Wykłady „Ewangelie synoptyczne” (48 godzin) „Pięcioksiąg” (24 godziny), „Historia zbawienia” (24 godziny) w Kolegium Filozoficzno-Teologiczne Polskiej Prowincji Dominikanów w Krakowie.

2. Wykłady „Wstęp do Pisma świętego” (12 godzin), „Ewangelia Mateusza” (12 godzin) w Dominikańskim Studium Filozofii i Teologii w Krakowie.

3. Wykłady „Wstęp do Pisma świętego” (12 godzin), „Jeruzalem w dziele Łukaszowym" (4 godziny) w Studium Dominicanum w Warszawie.

\section{Ks. dr Krzysztof Napora SCJ}

\section{Książka popularnonaukowa}

Uwierzyli Pismu i Stowu... Lectio divina do wybranych fragmentów Ewangelii (Kraków: Dehon 2018).

\section{Artykuły naukowe}

1. „Abraham - apostoł z Księgi Rodzaju”, Sympozjum 22/2 (2018) 131-144.

2. „Milczenie Boga w Biblii Hebrajskiej”, Sympozjum 23/1 (2019) 11-30.

3. „Czas w kapłańskim opowiadaniu o stworzeniu: dzień pierwszy (Rdz 1,3-5)", Verbum Vitae 35 (2019) 13-37. 


\section{Artykuły popularnonaukowe}

1. Tęsknota za Bogiem”, Echo Konopnicy 28/10-12 (2018) 4-5.

2. Jerycho - miasto po drodze...”, Galilea 28/7 (2019) 5-9.

3. „Szukam Serca Boga”, Czas Serca 28/5 (2018) 38-39.

4. „Największe przykazanie: Słuchaj, Izraelu...”, Czas Serca 28/6 (2018) 38-39.

5. „Inną drogą wrócili do siebie...”, Czas Serca 29/1 (2019) 38-39.

6. „Może wyda owoc”, Czas Serca 29/2 (2019) 38-39.

7. „Czy poszli za Nim...?”, Czas Serca 29/3 (2019) 38-39.

8. „Abba...”, Czas Serca 29/4 (2019) 38-39.

\section{Sympozja}

1. Referat „Milczenie Boga w Piśmie świętym” wygłoszony podczas konferencji „Na progu Słowa. Odkryć na nowo sens milczenia” (Kraków, 19.05.2019).

2. Referat „Lecture de Couronne d'Amour au Sacré-Cœur dans la clé de la Bible" wygłoszony na międzynarodowej konferencji poświęconej dziełu o. Leona J. Dehona „Couronne d'Amour” (Clairfontane 9-11.09.2019).

\section{Praca dydaktyczna}

1. Sesja „Wy niegdyś knuliście zło, Bóg jednak zamierzyt to jako dobro... (por. Rdz 50,20). Biblijne opowiadanie o Józefie (Rdz 37-50)" dla Szkoły Biblijnej Archidiecezji Gdańskiej (Gdańsk, 30.11 - 2.12.2018).

2. Wykłady pastoralno-biblijne „Ja jestem Józef wasz Brat. Na biblijnych ścieżkach braterstwa" dla Sióstr Franciszkanek Misjonarek Maryi (Lublin, lipiec 2019).

3. Współorganizacja i współprowadzenie kursów Abraham i Dawid w ramach szkoły biblijnej Dabar (Jerozolima, 16-31.08.2019).

4. Cykl comiesięcznych wykładów dla Sióstr Karmelitanek w Dysie.

5. Wykład „Dzieło Deuteronomistyczne” w Wyższym Seminarium Misyjnym Księży Sercanów w Stadnikach (30 godzin).

6. Wykład „Dzieło Kronikarskie” w Wyższym Seminarium Misyjnym Księży Sercanów w Stadnikach (30 godzin).

\section{Działania popularyzujące Biblię}

Cykl audycji „Szukając Słowa Bożego” nadawanych w Radiu Maryja. 


\section{Ks. dr hab. Andrzej Piwowar}

\section{Artykuły naukowe}

1. „Abraham w Pochwale Ojców (Syr 44,19-21)”, Collectanea Theologica 88/4 (2018) 75-123.

2. „Nowy podręcznik do nauki składni nowotestamentalnej greki. Analiza merytoryczno-dydaktyczna”, Biblical Annals 9/3 (2019) 547-567.

\section{Komentarze liturgiczne}

1. „22 ndz. zwykła C: Syr 3,17-18.20.28-29”, Biblia w liturgii Mszy Świętej. 22-28 tydzień zwykly (red. A. Paciorek - F. Mickiewicz) (W Drodze do Emaus 7; Częstochowa: Edycja Świętego Pawła 2019) 26-27.

2. „24 ndz. zwykła A: Syr 27,30 - 28,7”, Biblia w liturgii Mszy Świętej. 22-28 tydzień zwykly (red. A. Paciorek - F. Mickiewicz) (W Drodze do Emaus 7; Częstochowa: Edycja Świętego Pawła 2019) 136-138.

3. „30 ndz. zwykła C: Syr 35,12-14.16-18”, Biblia w liturgii Mszy Świętej. 29-34 tydzień zwykty (red. A. Paciorek - F. Mickiewicz) (W Drodze do Emaus 8; Częstochowa: Edycja Świętego Pawła 2019) 88-89.

4. „4 tydz. zw. piątek (II): Syr 47,2-11”, Biblia w liturgii Mszy Świętej. 1-7 tydzień zwykty (red. A. Paciorek - F. Mickiewicz) (W Drodze do Emaus 4; Częstochowa: Edycja Świętego Pawła 2018) 222-224.

5. „6 ndz. zwykła A: Syr 15,15-20”, Biblia w liturgii Mszy Świętej. 1-7 tydzień zwykty (red. A. Paciorek - F. Mickiewicz) (W Drodze do Emaus 4; Częstochowa: Edycja Świętego Pawła 2018) 302-303.

6. „7 tydz. zw. poniedziałek (I): Syr 1,1-10”, Biblia w liturgii Mszy Świętej. 1-7 tydzień zwykly (red. A. Paciorek - F. Mickiewicz) (W Drodze do Emaus 4; Częstochowa: Edycja Świętego Pawła 2018) 393-395.

7. „7 tydz. zw. wtorek (I): Syr 2,1-11”, Biblia w liturgii Mszy Świętej. 1-7 tydzień zwykty (red. A. Paciorek - F. Mickiewicz) (W Drodze do Emaus 4; Częstochowa: Edycja Świętego Pawła 2018) 400-402.

8. „7 tydz. zw. środa (I): Syr 4,11-19”, Biblia w liturgii Mszy Świętej. 1-7 tydzień zwykty (red. A. Paciorek - F. Mickiewicz) (W Drodze do Emaus 4; Częstochowa: Edycja Świętego Pawła 2018) 407-409.

9. „7 tydz. zw. czwartek (I): Syr 5,1-8”, Biblia w liturgii Mszy Świętej. 1-7 tydzień zwykly (red. A. Paciorek - F. Mickiewicz) (W Drodze do Emaus 4; Częstochowa: Edycja Świętego Pawła 2018) 413-415.

10. „7 tydz. zw. piątek (I): Syr 6,5-17”, Biblia w liturgii Mszy Świętej. 1-7 tydzień zwykty (red. A. Paciorek - F. Mickiewicz) (W Drodze do Emaus 4; Częstochowa: Edycja Świętego Pawła 2018) 419-421. 
11. „7 tydz. zw. sobota (I): Syr 17,1-15”, Biblia w liturgii Mszy Świętej. 1-7 tydzień zwykty (red. A. Paciorek - F. Mickiewicz) (W Drodze do Emaus 4; Częstochowa: Edycja Świętego Pawła 2018) 426-428.

\section{Sympozja}

1. Referat „Biblijne pojęcie prawdy” wygłoszony podczas Kongresu Biblijnego Archidiecezji Przemyskiej (21.09.2019).

2. Członek rady programowej sympozjum „Zapachy starożytności” (17.05.2019).

\section{Recenzje}

1. Recenzent dwóch prac magisterskich obronionych na Wydziale Teologii KUL.

2. Anonimowy recenzent wydawniczy ośmiu artykułów naukowych.

\section{Udział w komisjach}

Sekretarz komisji ds. habilitacji ks. dr. Adama Kubisia (Wydział Teologii KUL, 2019).

\section{Inne}

Współodpowiedzialny za rewizję tłumaczenia VI wydania Biblii Tysiąclecia.

\section{Ks. prof. dr hab. Stefan Szymik MSF}

\section{Artykuły naukowe i hasła encyklopedyczne}

1. „Kazanie na Górze (Mt 5-7) w wykładzie Marcina Lutra”, Studia Nauk Teologicznych PAN 13 (2018) 27-43.

2. „M. Lutra wiodące idee interpretacji Kazania na Górze (Mt 5-7) w ich kontekście historycznym i teologicznym”, Teologia. Kultura. Społeczeństwo. Czasopismo Koła Naukowego Teologów KUL 4 (2018) 44-57.

3. „Gniewne oblicze Pana. Hermeneutyka kilku biblijnych kolokacji”, Verbum Vitae 34 (2018) 15-36.

4. „«Kto wierzy, ma życie wieczne» $(\mathrm{J} 6,47)$. Wiara w Jezusa Chrystusa warunkiem zbawienia i życia wiecznego", Jest nadzieja, bo jest życie wieczne (red. B. Kulik - W. Pałęcki) (Lublin: Wydawnictwo KUL 2018) 15-30. 
5. „«Portemus et imaginem caelestis» (1 Kor 15,49 Vg). Wybrane aspekty antropologii św. Pawła - apostoła, teologa i mistyka”, Czym jest człowiek, że o nim pamiętasz? (Ps 8,5). Antropologia w Piśmie Świętym (red. T. Bąk) (Analecta Biblica Lublinensia 16; Lublin: Wydawnictwo KUL 2019) 136-149.

6. „«Oto prawdziwy Izraelita» (J 1,47). Paradygmatyczna funkcja Natanaela w czwartej Ewangelii”, „Dla dobra Jego Ciała, którym jest Kościót” (Kol 1,24). Księga Pamiątkowa Księdza Profesora Antoniego Paciorka z okazji Złotego Jubileuszu Kapłaństwa (red. G.M. Baran) (Częstochowa: Edycja Świętego Pawła 2019) 451-463.

7. „Lektura Biblii i dar Bożego Ducha”, Zamieszkać w Stowie 1 (2019) 118-130.

8. „Grzybek Stanisław Wilhelm”, Encyklopedia 100-lecia KUL (red. E. Gigilewicz et al.) (Lublin: Wydawnictwo KUL 2018) I, 298.

9. „Jak Rozumieć Pismo Święte”, Encyklopedia 100-lecia KUL (red. E. Gigilewicz et al.) (Lublin: Wydawnictwo KUL 2018) I, 415-416.

10. ,Jankowski Bogdan (Augustyn)”, Encyklopedia 100-lecia KUL (red. E. Gigilewicz et al.) (Lublin: Wydawnictwo KUL 2018) I, 424-425.

11. „Materiały Pomocnicze do Wykładów z Biblistyki”, Encyklopedia 100-lecia KUL (red. E. Gigilewicz et al.) (Lublin: Wydawnictwo KUL 2018) II, 27.

12. „Międzynarodowe Jesienne Dni Biblijne”, Encyklopedia 100-lecia KUL (red. E. Gigilewicz et al.) (Lublin: Wydawnictwo KUL 2018) II, 51.

13. „Wiosenne Dni Biblijne”, Encyklopedia 100-lecia KUL (red. E. Gigilewicz et al.) (Lublin: Wydawnictwo KUL 2018) II, 539.

14. Recenzja: J. Nowińska, Co styszysz poza stowem? «Sound design» Apokalipsy św. Jana (Rozprawy i Studia Biblijne 47; Warszawa: Vocatio 2016), Verbum Vitae 34 (2018) 511-518.

\section{Redakcja naukowa książki}

Redakcja naukowa polskiego wydania: S. Bazyliński, Wprowadzenie do studium Pisma Świętego, wyd. 2, poprawione i poszerzone (Kielce: Jedność 2019).

\section{Sympozja}

1. „Nauczanie i wychowanie w czasach Jezusa Chrystusa. Refleksja biblijna w 50 rocznicę istnienia WSD MSF w Kazimierzu Biskupim”, WSD MSF Kazimierz Biskupi - oddział Wydziału Teologii UAM (Poznań, 16.10.2018).

2. „Epikurejskie tło negacji zmartwychwstania umarłych w Koryncie (1 Kor 15)?”, XIV Międzynarodowe Jesienne Dni Biblijne „Rosa Twoja jest rosa świattości, a ziemia wyda cienie zmarlych (Iz 26,19). Zmartwychwstanie w Biblii i kulturze starożytnej basenu Morza Śródziemnego" (Lublin, KUL, 23-24.10.2018). 
3. „Wychowanie dzieci w tradycji biblijnej”, XIX Sympozjum naukowe „Rodzina - Wychowanie - Sens", WSD MSF Kazimierz Biskupi - oddział Wydziału Teologii UAM (Poznań, 27.02.2019).

4. „Prezentacja II wydania Wprowadzenia do studium Pisma Świętego o. prof. Stanisława Bazylińskiego OFMConv (Kielce: Jedność 2019)” (Wigry, 1618.09.2019).

\section{Szkolenia}

Udział w trzech kursach w ramach projektu Zintegrowany Program Podnoszenia Kompetencji studentów i pracowników Katolickiego Uniwersytetu Lubelskiego Jana Pawła II

1. Kurs innowacyjnych umiejętności dydaktycznych (32 godzny):

- model „learning-by-doing” w pracy dydaktycznej;

- model „design-thinking” w pracy dydaktycznej.

2. „Tworzenie publikacji cyfrowych” (30 godzin).

3. „Innowacyjne prezentacje multimedialne dla wykładowców” (wymiar 30 godz.).

\section{Udział w komisjach}

1. Recenzent w postępowaniu habilitacyjnym ks. dr. Marcina Kowalskiego, Wydział Teologii KUL (13.01.2019).

2. Recenzent w postępowaniu habilitacyjnym ks. dr. Adama Kubisia, Wydział Teologii KUL (8.05.2019).

\section{Kwerenda}

Pobyt, kwerenda biblioteczna i praca naukowa w Fachbereichsbibliothek Theologie, Universitätsbibliothek der Universität Wien (Wiedeń, 8-14.07.2019).

\section{Praca dydaktyczna}

1. Wykłady z Nowego Testamentu (Ewangelie synoptyczne) w WSD MSF Kazimierz Biskupi - oddział Wydziału Teologii UAM, Poznań (45 godzin).

2. Wykłady z metodologii biblijnej (Metody interpretacji Pisma Świętego), Kurs Formacji Biblijnej Archidiecezji Lubelskiej (16 godzin). 


\section{Ks. prof. dr hab. Henryk Witczyk}

\section{Artykuły naukowe}

1. „Gniew Boga jak gniew człowieka?”, Verbum Vitae 33 (2018) 7-18.

2. „Czemu służy «gniew» Boga”, Verbum Vitae 34 (2018) 7-11.

3. „Dlaczego przez czas do wieczności?”, Verbum Vitae 35 (2019) 7-9.

4. „Wielowymiarowa re-kreacja postaci literackich”, Biblica et Patristica Thoruniensia 11/2 (2018) 177-195.

5. „Wiarygodność historyczna Ewangelii - nowe kierunki badań”, Historia Wiara - Nauka. Źródła poznania Jezusa Chrystusa (red. P. Artemiuk) (Biblioteka Teologii Fundamentalnej 13; Płock: Płocki Instytut Wydawniczy Lublin: Stowarzyszenie Teologów Fundamentalnych w Polsce 2018) 70-116.

6. „Wieczerza Pańska - «pamiątka» Chrystusowej męki, śmierci i zmartwychwstania jako ekspiacyjnej Ofiary «za wielu» i Ofiary Nowego Przymierza (1 Kor 11,23-27; Łk 22,19-20)", The Biblical Annals 8/4 (2018) 545-565.

7. „Wizja miłości mężczyzny i kobiety w Pieśni nad pieśniami. Implikacje psychologiczno-pedagogiczne", Roczniki Pedagogiczne 11(47)/3 (2019) 37-57.

8. „Bóg i Jezus Chrystus nie błogosławi relacjom homoseksualnym”, artykuł w wersji elektronicznej opublikowany 5.07.2019 r. na portalu Opoka (https:// opoka.org.pl/biblioteka/P/PS/kswitczyk_homoseksualizm.html).

\section{Recenzja i laudacja}

1. „Ocena dorobku naukowego, pracy dydaktycznej i działalności organizacyjnej ks. prof. dr. hab. Romana Bartnickiego", Warszawskie Studia Teologiczne 31 (2018) 13-21.

2. „Laudacja na cześć ks. prof. Waldemara Chrostowskiego z okazji nadania honorowego członkostwa w Stowarzyszeniu Biblistów Polskich", Zeszyty Naukowe Stowarzyszenia Biblistów Polskich 16 (2019) 434-446.

\section{Papieska Komisja Biblijna}

Udział w sesji plenarnej Papieskiej Komisji Biblijnej (Kongregacja Nauki Wiary, Watykan, $23.04-3.05 .2019$ ).

\section{Promocje prac doktorskich}

1. Stanisław Sadowski, Udzial św. Piotra w męce, śmierci i zmartwychwstaniu Chrystusa na podstawie J 18-21 (KUL, wrzesień 2019). 
2. Valery Martsinouski, Chrześcijanie w obliczu Dnia Pańskiego. Zarys parenezy eschatologicznej $w$ Listach do Tesaloniczan (1Tes 4,13-18; 5,1-11; 2Tes 2,1-17) (KUL, wrzesień 2019).

\section{Ks. dr Arnold Zawadzki}

\section{Artykuły naukowe}

1. „Kim jest oblubieniec w przypowieści o dziesięciu pannach (Mt 25,1-13)? Między tradycyjnymi i współczesnymi próbami zrozumienia”, The Biblical Annals 9/2 (2019) 353-396.

2. „Una nuova accezione del verbo עבר in Os 10,11bc”, The Biblical Annals 9/3 (2019) 463-480.

\section{Działalność odczytowa}

1. „Czy lektura żydowska Biblii jest potrzebna chrześcijanom?”, XXI Ogólnopolski Dzień Judaizmu w Kościele Katolickim (Łódź, 16-17.01.2019).

2. „Biblijne podstawy nauczania o małżeństwie i rodzinie w adhortacji Amoris laetitia papieża Franciszka”, IV Synod Archidiecezji Łódzkiej (2.02.2019).

\section{Promotor pracy magisterskiej}

Michał Kardynia, Kerygmat Pawłowy w dziele Nowej Ewangelizacji - Dz 13,44-52 (Papieski Wydział Teologiczny w Warszawie, 1.03.2019).

\section{Promotor prac dyplomowych}

1. Dorota Krakowiecka, Metafory zbawienia uśw. Pawła (Papieski Wydział Teologiczny w Warszawie, 30.06.2019).

2. Lilla Mianowska, Zmartwychwstanie i nowe zrozumienie osoby Jezusa (Papieski Wydział Teologiczny w Warszawie, 30.06.2019).

3. Hanna Zienkiewicz, Rut - kobieta wierzaca pośród trudów życia (Papieski Wydział Teologiczny w Warszawie, 30.06.2019).

4. Ewa Michalak, Miłość rodzicielska w Piśmie Świętym jako obraz miłości Boga do człowieka (Papieski Wydział Teologiczny w Warszawie, 30.06.2019). 


\section{Działalność dydaktyczna}

Wykłady z Pism Janowych w Wyższym Seminarium Duchownym Ojców Franciszkanów w Łodzi (60 godzin).

\section{Inne}

Redaktor Komisji ds. Rewizji Starego Testamentu VI wydania Biblii Tysiaclecia (współprzewodniczenie spotkaniom Komisji).

\section{Ks. dr Marcin Zieliński}

\section{Recenzje}

1. Giancarlo Biguzzi, Paura e consolazione nell'Apocalisse (Bologna: Edizioni Dehoniane Bologna 22017), The Biblical Annals 9/2 (2019) 413-416.

2. Luca Mazzinghi, Weisheit (Internationaler Exegetischer Kommentar zum Alten Testament; Stuttgart: W. Kohlhammer 2018), The Biblical Annals 9/1 (2019) 217-220.

\section{Sympozjum}

Wykład „Biblijny obraz młodości”, 51. Tydzień Eklezjologiczny „Młodzi w Kościele" (KUL, Lublin, 27.02.2019).

\section{Współpraca międzynarodowa}

Wykłady gościnne na Papieskim Uniwersytecie Urbaniana: „Joy and Sorrow in the Book of Wisdom" (Rzym, 7-22.10.2018).

\section{Kwerenda}

Kwerenda naukowa na Papieskim Uniwersytecie Urbaniana (Rzym, 05-27.10.2018).

\section{Szkolenia}

1. Projektowanie i prowadzenie kursów akademickich online. Obsługa platformy Moodle - kurs internetowy (2018/2019). 
2. Innowacyjne prezentacje multimedialne (30 godzin, 2019).

3. Obsługa Jednolitego Systemu Antyplagiatowego (5 godzin, 6.11.2018).

4. Innowacyjne metody i środki nauczania (40 godzin, 2018).

\section{Promocja pracy doktorskiej}

Promotor pomocniczy pracy: Valery Martsinouski, Chrześcijanie w obliczu Dnia Pańskiego. Zarys parenezy eschatologicznej w Listach do Tesaloniczan (1 Tes 4,13-18; 5,1-11; 2 Tes 2,1-17) (KUL, wrzesień 2019).

\section{Działalność medialna i dydaktyczna}

1. Wykłady w ramach Telewizyjnego Uniwersytetu Biblijnego, trzy wykłady w roku akademickim 2018/2019.

2. Wykład „Wojna i przemoc w Biblii” w ramach Kursu Formacji Biblijnej w roku 2018/2019 (16 godzin).

3. Ogólnopolski Konkurs Biblijny dla Seminarzystów Diecezjalnych i Zakonnych 2019 - przewodniczący Komisji Konkursowej.

4. Warsztaty Biblijne dla Kleryków - finalistów Ogólnopolskiego Konkursu Biblijnego dla Seminarzystów Diecezjalnych i Zakonnych 2019 (Bieszczady, 8-14.10.2019).

5. Prowadzenie szkoleń w ramach podnoszenia kompetencji katechetów z archidiecezji lubelskiej - 3 grupy (łącznie 90 godzin, Dąbrowica, maj-czerwiec 2019). 
